\title{
The Public Spectacle of Physical Punishment in Malone James's The Book of Night Women
}

\author{
Yingjie Liu \\ College of Literature and Journalism \\ Sichuan University \\ Chengdu, China
}

\begin{abstract}
The public spectacle of the physical punishment of black slaves in Malone James's The Book of Night Women is an academic problem worth discussing. Physical punishment, as a normal punishment in the daily life of black slaves, refers not only to the punishment itself, but also to a dynamic public spectacle. In the book, the corporeal punishment that has become a public spectacle is divided into the public spectacle of official punishment and the public spectacle of lynching punishment due to the different executors. The former has the functions of purging evil, restoring damaged social order and uniting the white people. The latter has the functions of repressing people, awing people, letting out white people's anxiety and showing their power. The public spectacles of the two types of punishment scenes, no matter what the above functions they are equipped with, are a reflection of the power hierarchy relationship and are representations of the colonial system at that time.
\end{abstract}

Keywords-Malone James; The Book of Night Women; physical punishment; public Spectacle

\section{INTRODUCTION}

"The Book of Night Women" is one of the greatest books by Jamaican writer Malone James. The book was well received at that time, with critics calling it was Malone James's "darkly powerful second novel" (Buckley 2009). Other critics argue that it is " not merely a historical novel. It is a book as heavily peopled and dark as the night in this isolated and brutal place" (Straight 2009).The above comments all mentioned the word "dark", because "the book is not just about the institutionalised hatred inherent in slavery", Akbar (2009) "the book is full of such racial anger". (Buckley, 2009) The source of this racial anger is not just the colonial system itself, what is more obvious one is the terrible experience of the slavery of the black people. The work focuses on the daily miserable life of black slaves in Jamaica's plantations in the late 18th and early 19th centuries. Among these descriptions, punishment scenes of the black slaves are not to be ignored and mainly focus on the physical punishment.

It is emphasized here that the objects of punishment for black slaves are their bodies, not other objects, such as property, personal freedom or spirit in that for slaves, the body was both a tool and a possession. The body of the Negro was the only place where the power of the other could be exercised, and where the punishment of the colonists could be exercised. Therefore, the description of black slaves' punishment scenes in the books focuses on the physical punishment. Of course, the slave's body was not only a place for punishment, it was also inevitably involved in economic and political power relations. "Power relations have an immediate hold upon it; they invest it, make it, train it, torture it, force it to carry out tasks, to perform certain ceremonies, to emit signs". (Foucault 1995:25) Thus, the slave's body could be controlled and trained for the colonists. In the same way, the punishment of the slave body is optional and controllable. This kind of choice and control is embodied in the Book of the Night Women as the punishment of the slaves' bodies become a public spectacle, namely the public spectacle of punishing the slaves' bodies.

Spectacle is a compound concept, which is derived from the Latin words "specere" and "spectae", meaning to be seen and watched. It not only refers to the simple and static description to the world and the external phenomenon of the life, but also regards these descriptions as presented visual objects. In other words, the spectacle not only refers to the appearance itself but also refers to its quality of being watched. Because "the spectacle appears at once as society itself, as a part of society" (Debord 1995:12), moreover, spectacle " is not a collection of images; rather, it is a social relationship between people that is mediated by images." (Debord 1995:12) The same is true of the scene in the Book of the Night Women about the physical punishment of the Negro. It is not only the punishment scene itself, but also the power relations between the punisher, the punished, the active observer and the passive observer. As a further definition of spectacle scope, "public" in public spectacle is opposite to "private". "Public" has the nature of being public, open, displayed, publicly known and accessible. Therefore, the public spectacle of slaves' punishment scene refers to that when the slaves are punished, the punisher were not using a hidden way in hidden places but carry out the punishment in public in a propaganda way. This has a resemblance with public execution. There are a lot of audiences and the scene has unconsciously become a dynamic spectacle to be watched and enjoyed. Such a spectacle of punishment, like public execution, is a declaration of power. It is not merely "as a ritual of armed law" (Foucault 1995:50), but also is a boast of the imbalance of power and the irreversible tilt of both sides. In the Book of the Night Women, there are more public spectacle scenes of slaves' punishment, and there is a difference between the public spectacle of the official punishment and lynching punishment. 
Here, the public spectacle of official punishment scenes and the public spectacle of lynching punishment scenes are different from each other mainly in the perpetrators of the punishment. The former is executed by an official government agency, the latter is by private people. Punishment imposed by official government agencies on slaves is called official punishment, whereas punishment imposed on slaves by private plantation owners or supervisors is called lynching. Official punishment usually refers to that slaves are transferred to the relevant official court after making mistakes and be punished according to the relevant regulations of slave law. The court for slaves "consists of two magistrates and three free landholders (with slightly different forms of organizations in different places) to trial the slaves for their small mistakes and crimes", (Hurwitz, 1977:126) sometimes the big crimes. In the book, the perpetrators of such official punishment are mostly soldiers of the colonial government and other security personnel. The lynching means that the slave will not hand over to the official institution after making the mistake, but will be punished by the owner or the supervisor. The perpetrators of such punishment in the book are mostly white masters, white overseers or black overseers who obey orders. In the book, lynching is far more than official punishment in numbers, and it is the daily punishment suffered by most black slaves. Although the perpetrators of the two types of punishment are different, the public exhibition nature of the punishment is the same, that is, both of them have turned the punishment into a public spectacle for viewing.

\section{The Public Spectacle of Official Punishment SCENES}

In the Book of the Night Women, the public spectacle description of the scene of official punishment is seen everywhere. There are two typical scenes. Typical scenes 1 : Lilith burns Coulibre and Francine is wrongfully executed. "More hour later the commander of the militia say they suspect that Francine was part of the plot and was trying to run away." (James 2009: 230) "They whip Francine first and she scream and bawl,then her back,then her belly.they push her down on the floor and pin her with the they boots." (James 2009:230) "so they heat a poker and start to brand all over her body. When she still didn't talk they spread her leg wide and brand her pussy." (James 2009:230) They did the same thing to the slave boy. "Every nigger confess. The commander lock them up in the gaol for trial. "(James 2009:230) This is one typical scene description of the execution of official punishment.

Typical scenes 2: The scene of punishment after the great Negro riots of 1801."By the night, all of Middlesex County smell of flesh. bleeding flesh, burnin' flesh, starving flesh and rotting flesh ."(James 2009:403) "At Worthy Park, most negro get shot in the head, then hang until they rot to the bone. At Ascot Pen, most get whipped, then hang up to burn". (James 2009:403) Though we cannot tell from the description to the scene whether the punishment is official punishment or lynching punishment, we can conclude it to mainly be the official punishments in that the militia disposed the slaves of Montpellier's plantation at the disposal of their master, Mr. Humphrey.
Official punishment, as mentioned above, should be carried out differently from lynching punishment. It should follow certain procedures, such as evidence collection and mistakes verification. The execution of official punishment shall also be carried out in accordance with the provisions of the uniform slave law. For example, in the Uniform Slave Law, "Indiscriminate killing of slaves should be sentenced to death. To flog a slave arbitrarily or to punish a slave in any other way that is too cruel should also be punished."(Hurwitz, 1977:126)However, in both of the above two scenes of official punishment in the Book of the Night Women, the court is absent. There is no reasonable evidence collection, no fair appeal, and the execution of official punishment is only a simple and brutal torture to extract confessions. Moreover, official punishment is highly consistent with lynching punishment in terms of the cruelty of torture. The lynching in the process of the execution of official punishment is not only a demonstration of the supreme power of white people, but also a part of the punishment spectacle, because "the spectacle, though it turns reality on its head, is itself a product of real activity". (Debord 1995:14)The public spectacle of mixed scenes of official punishment with the characteristics of lynching is mainly reflected in the following aspects.

First, the punishment spots in scene 1 is the square of the Spanish town, and in scene 2 is Worthy Park. Squares and parks are open areas for group activities, and their openness is self-evident. Secondly, from the perspective of the ways of punishment, the punisher does not adopt the method of secret slaughter, but uses the methods of hanging, burning and flogging slaves which have a high level of displaying. Such means declares the antagonism between us and the enemy and the disparity in power in a way that shows off in an ostentatious manner. Of course, the public spectacle of official punishment on the physical punishment of black slaves is not just a simple demonstration of the great disparity in the power of the enemy. It has other functions. As one of the means of violent colonization, it also has the functions of repressing people, awing people, purging evil and uniting white people. It's just that in the Book of the Night Women, the scene of official punishment does not specifically mention the presence of a large number of other slaves at the scene. Therefore, the repression and deterrent function it has on the slaves was not seen. On the contrary, it is clearly mentioned that a large number of white people are present in the scene of official punishment. Therefore, it only proves its function for white people, namely, the function of purging evil and uniting white people.

In terms of the repair function of purging evil, its targets are mainly the white punishers. For the white punishers, the exhibition factor inherent in the public spectacle of the scene of official punishment is actually a symbolic ceremony to eliminate evil. Such ceremony has the function of repairing. First of all, the ritual restores the power polluted by the evil by the punishment scenes. For the public spectacle of punishment scenes seems to be a "hust and every day, belongs to a whole series of great rituals in which power is eslipsed and restored". (Foucault 1995:48)The show-off of punishment is a sign of the return of power. It's a restore of the power and is a cleansing ritual to the power that has been polluted by the evil. The 
ceremony achieved the ultimate triumph of power through a slow process of punishment and dramatic anger. Second, the ritual restores the daily life destroyed by evil through the scene of punishment. "By ritual and speech what has passed is restated so that what ought to have been prevails over what was, permanent good intention prevails over temporary aberration." (Douglas 2001:68) The public spectacle of the above scenes of official punishment made the former crimes of black slaves be recognized and recounted again. Their punishment is now several times more punitive, which relieves the white man's sudden anxiety and fear, and allowed their normal life to continue, the black slave's sins to be purged in punishment, and the white man's wounds to be healed.

In terms of uniting the white people, it also targets the disadvantaged white people in colonial lands. The public spectacle of official punishment scenes has activated the potential collective anxiety of white people due to the huge gap in the proportion of the population (white and black) in colonial states, which advanced the unity of the white people. Because of the public spectacle of the scene of official punishment, the cruel evil of black slaves was shown and the tragic story of persecuted white people was spread. The public spectacle of punishment became an obvious political ritual. It "follows highly structured and standardized procedures and has its own specific venue and time". (Koser 2015:12). This is the case with the above scene of official punishment where there are specific places and fixed punishment procedures. What's more, it "provides a way for people to get involved in the drama and see their corresponding characters." (Koser 2015:14) However, it "does not just define the role, it also evokes emotional reactions." (Koser 2015:14)The emotional response to the above scenes of official punishment is white people's anger and collective anxiety, which manifests itself in "solidarity among whites" (or "political solidarity").

The term "solidarity among whites" refers to "Another instructive indication of the aristocratic or pseudoaristocratic derivation of colonial racism, which linked colonial rulers from different national metropoles, whatever their internal rivalries and conflicts". (Anderson 2006:152-153) This solidarity is a sign of spontaneous anxiety. It is the result of psychological stimulation after participation in the above ceremonies. It can be revealed in the above two cases in that local colonialists of British, Spanish or French descent are united in solidarity. They witnessed or executed the execution of official punishment as direct or indirect participants in the execution of official punishment. The public spectacle of official punishment scenes activates the white-black boundaries that "separate us from them" (Tilly 2011:35) White people, regardless of their nationality, are on one side of the line, while black people, regardless of being good or evil, are forced to be divided on the other side. At this time, the public spectacle of the scene of official punishment became the catalyst and adhesive of white people's solidarity, which promoted white people's solidarity.

\section{The Public SPectacle of LyNCHING PUnishment SCENES}

The number of the public spectacle scenes of lynching punishment in the Book of Night Women is also numerous.
Among them, the public spectacle scene of lynching punishment has the difference between normal and abnormal, but both are famous for their cruelty. The normal scene of lynching punishment in the book is to execute punishment within the scope of punishment means prescribed by law, such as whipping, etc. The abnormal scene of lynching punishment means that the punishment is not in accordance with the punishment provisions of the slave law but use some kind of punishment that challenges the bottom line of human physiology and morality and physical limits, which are numerous in the book. Typical scenes of normal lynching punishment include the scene where Lilith and Homer are whipped. The typical scenes of abnormal lynching include Mrs. Rogert's lynching and Humphrey's hanging after the riot.

Among those normal lynching scenes, Lilith and Homer's punishment scene is the most typical. "The two negroes carry Lilith to the cotton tree. She struggling and she bawling and she screaming". (James 2009:163) "The tall negro swing and the whip lash Lilith straight cross her back. Lilith scream so hard that she cough. The negro lash her again. Lilith struggled... Some people watch her face, some watch her breast, and some watch her arse and pussy ... The new pain wake up the old pain that the massa done give her. She bawling like a girl, not a woman, and she screaming" (James 2009:163). The scene of Homer being whipped is similar to that of Lilith, "Richardson notice and the fourth and fifth lash come harder, Homer spinning worse and the fifth lash strike her breasts. Homer scream. The whip cut through her black skin leaving a white gash that turn red with blood, then pink when blood start to flow down her skin"(James 2009:383).

In the above normal scenes of lynching punishment, the characteristics of public spectacle are obvious. It is mainly presented in the following two aspects: One is that the punishment is carried out with a large number of audience. When Lilith and Homer were whipped, for example, other slaves were gathered to watch the punishment. This can be seen from the narrative that "Some people watch her face, some watch her breast, and some watch her arse and pussy". (James 2009:163) The second is the exhibition nature of the punishment implementation. This is similar to official punishment, in which the offender is suspended from a high place, usually in a tree. The punishment itself has a strong flavor of demonstration, what's more, the other slaves were asked to watch it, and all these factors make this kind of normal scene of lynching punishment become a public spectacle. The public spectacles of such normal lynching punishment are similar to the public spectacles of the abovementioned public spectacles of official punishment in their functions. However, the black slaves were the only audiences to the public spectacles of lynching punishment, this kind of punishment are only responsible for suppressing people, awing people, and letting out anxieties.

The public spectacle of normal lynching punishment has the function of repressing and awing people. Its target is mainly other unerring slaves who are gathered to watch the scene of punishment. It hopes to achieve something similar to the effect of public executions. "The aim was to make an example, not only by making people aware that the slightest 
offence was likely to be punished, but by arousing feelings of terror by the spectacle of power letting its anger fall upon the gulity person". (Foucault 1995:58) So was the purpose of public spectacles of the black slaves' punishment scenes, because in public exhibition of punishment, "It was the principle of the communication between the crime and the punishment, it was also the exacerbation of the punishment in relation to the crime. It provided the spectacle with both truth and power "(Foucault 1995:56). What's more, by public punishment, it can deter other slaves. As a result, they can suppress their potential rebellion or discontent due to fear, thereby eliminating the possibility of the rebellion. Of course, in the above normal scene of lynching, the function of awing people is realized through the pliability of the slaves' bodies. This tameness is manifested by the fact that the bodies of the black slaves are "it is largely as a force of production that the body is invested with relations of power and domination". (Foucault 1995:26) The big premise, of course, is that "its constitution as labour power is possible only if it is caught up in a system of subjection". (Foucault 1995:26) Here the slaves' bodies were the labor force controlled by the colonial system. Since the tameness of the slaves' bodies is represented by the interference of power relations, such interference in the work is presented as lynching punishment. Because the flesh of the black slave who was punished at this time is in an absolutely dominant power relationship. "Of a power that not only did not hesitate to exert itself directly on bodies, but was exalted and strengthened by its visible manifestations".(Foucault 1995:57) Whipping in the normal punishment of lynching is the conventional means to tame the body. Through the rise and fall of the whip, through the blurring of flesh and blood, it completes the ritual of taming the body. The ceremony "by the scar it leaves on the body" (Foucault 1995:34) .

However, when the public spectacles of normal punishment of lynching bear the function of repressing and awing people, it can also sometimes cause negative effects. In other words, "People drawn to the spectacle intended to terrorize it, could express its rejection of the punitive power and sometimes revolt." (Foucault 1995:59). For "people never felt closer to those who paid the penalty than in those rituals intended to show the horror of crime and the invincibility of power; never did the people feel more threatened, like them by a legal violence exercised without moderation or restraint ". (Foucault 1995:63) This negative effect is evident in the Book of the Night Women. The sight of the black slave girl, Homer, being whipping with bloody stripes confirmed Lilith's determination to join the uprising. The negative effect is due to the fact that "violent rituals often reflect and reinforce existing inequalities". (Tilly 2011:92) Thus, the public spectacle of lynching punishment has been transformed into a kind of violent ceremony, which is intended to strengthen the existing inequality system, that is, to suppress and intimidate people. But it also reflects the absolute inequities of the colonial system and that of the powers involved. This inequality is the existing state. The violent ritual of public spectacles of the lynching highlights this inequality. As a result, it is reasonable to provoke the psychological rejection of the slaves.

In the abnormal scene of lynching, lynching is not only a complete mockery of the slave law, but also a full expression of the evil imagination of the colonists. Sacco, the black slave who gave her a flower every day, was now Lilith "see honey on Sacco nakedness from head to foot. Sacco bawling and screaming so much that other nigger get a cloth and gag him". (James 2009:196) "There be Sacco, writhing and shaking and yelling into gag, him feet, back, chest and cocky all cover in black ants. They traveling all over him body and biting every inch ". (James 2009:196) It was Mrs. Roget, Miss Isobel's mother, who punished a slave who was responsible for watering her flowers every day. He was punished simply because his mistress, Mrs. Roget, "don't take too kindly to some flowers and sneeze and cough something dreadful ". (James 2009:196)

In addition, after the great Negro riots, Montpelier's punishment scenes of lynching are also unusual and extremely creepy. The captives who had been taken back to Montpellier were kept in cages, "Days pass and the cage take up with sweat, shit and dead nigger". (James 2009:403) Mr. Humphrey has created a new type of gibbets for revenge. "The gibbets bulid like a cage with an iron loop at the top for rope to hang through, two slat of iron that run down tha side and one down the front that make the metal cage like the shape of a man ... The mens throw down Achilles in the open gibbet. On the inside of the gibbet nails stick out and as they close it they stab right into Achilles' flesh. He go to scream again, but they shove an iron gag in him mouth too and he mutter like a monster ". (James 2009:407)

The public spectacle of the above abnormal lynching punishment, although similar in form to official punishment and normal lynching, or overlapping a little bit functionally, it highlighted the spectacles' reflection of power more than the other two, because "at the root of the spectacle lies that oldest of all social divisions of labor, the specialization of power". (Debord 1995:18) Although official punishment also reflects the supreme power of white people, the power of white people in official punishment is relatively moderate compared to the abnormal lynching. In the abnormal lynching spectacles, the power of white people is distorted after extreme expansion. This distortion is a reflection of the function of emotional catharsis. The first of the two unusual scenes of lynching are an outpouring of anxiety over the fear of black slaves. The latter is vindictive catharsis (the hanging planned by $\mathrm{Mr}$. Humphrey's). In both cases, the former is the application of the Scapegoat Theory. It is a kind of emotional tension that is eliminated by venting them to symbolic enemies (Geertz 1973:205) The latter is the extension of the loss-compensation mechanism, which is the expression of the frustration and revenge like what expressed in the old saying "eye for eye, tooth for tooth" (Coogan 2010:282). These two kinds of catharsis both show initiatives for the cathartics are those who are in charge. Without power, cathartic punishment is out of the question.

Mrs. Roget's sentence to Sacco's lynching punishment was, in effect, her use of power to vent her anxiety. First, she "projects her fear and anxiety on the other people". (Brown, 2003:79) (The "other" here was appointed to slaves.) Secondly, she used her power to inflict terrible punishment on the target slaves. The punishment that seemed to destroy the slave's body was in fact destroyed her own fear. Thirdly, when the object 
projected by fear is punished, her anxiety caused by fear is relieved and her original satisfaction is realized again. The primary satisfaction is "the ability to break social and moral norms without being punished."(Metz and others. 2005:82)It was through this catharsis that Mrs Roget returned to her normal life. Humphrey's hanging was a similar process, albeit a vindictive one. They are all using their power to repair and compensate their feelings.

\section{CONCLUSION}

In short, the description of the public spectacle of official punishment of the black slaves in the Book of the Night Women is not a simple description of the scene itself. It is a reflection of the social relations and power relations of the Jamaican colonies. The public spectacle of the physical punishment of black slaves not only clearly shows the instrumental personality of the black slaves and their state of lacking power, but also reflects the expansion of the power of the white people. In the work, the public spectacle of the physical punishment of black slaves is divided between the public spectacle of official punishment and the public spectacle of lynching punishment due to their different executors. In official punishment, the public spectacle of punishment scenes plays the role of uniting white people and eliminating evil. In lynching, the public spectacle of normal lynching punishment scenes has the function of suppressing and deterring other wronged slaves. The public spectacle of abnormal lynching punishment has the function of letting out the punisher's anxiety and showing off the power of white people. Of course, the function of the public spectacle of the above three punishment scenes is not absolute. There is more or less overlap between them, but the emphasis is different. These functions, whether from official punishment or lynching punishment, are in fact manifestations of colonial power relations. The spectacle of punishment itself has shown the incontestability of this hierarchical relationship.

\section{REFERENCES}

[1] Akbar, Arifa. Rev. of The Book of Night Women, by Marlon James. Independent [London]. Independent Print Ltd, 28 Aug. 2009. Web. 5 Oct. 2010

[2] Anderson, Benedict. Imagined Communities: Reflections on the Origin and Spread of Nationalism. London and New York: Verso.2006

[3] Buckley, Gail Lumet. "Vengeance Is Theirs." Rev.of The Book of Night Women, by Marlon James. Washington Post 17 Feb. 2009. Web. 5 Oct. 2010 .

[4] Coogan, Michael D.et al .The New Oxford Annotated Bible. Fourth Edition. New York: Oxford UP, 2010.

[5] Debord, Guy. The Society of the Spectacle. New York: Zone Books.1995.

[6] Douglas, Mary. Purity and Danger. London and New York: Routledge, 2001.

[7] Foucault, Micher. Discipline and Punish: the birth of prison. Trans.AlanSheridan .New York: Random House, 1995.

[8] Geertz, Clifford. The Interpretation of Cultures. New York: Basic Books, 1973.

[9] James, Marlon .The Book of Night Women. London: One world Publications, 2009

[10] Straight, Susan. Rev.of The Book of Night Women, by Marlon James. Los Angeles Times 8 Mar. 2009. Web. 5 Oct. 2010.
[11] Charles Tilly, The Politics of Collective Violence. translated by Xie Yue, Shanghai: Shanghai People's Publishing, 2011. 查尔斯 - 蒂利: 《集体暴力的政治》谢岳译上海：上海人民出版社，2011 年。

[12] David Koser, Rituals, Politics and Power. Translated by Wang Haizhou, Nanjing: Jiangsu People's Publishing, 2015. 大卫・科泽: 《仪式、政 治与权力》王海洲译 南京: 江苏人民出版社, 2015 年。

[13] Wu Qiong, Ed. The Pleasure of Staring: Psychoanalysis of Movie Texts. Beijing: Renmin University of China press, 2005. 吴琼编: 《凝视的 快感一电影文本的精神分析》北京: 中国人民大学出版社, 2005 年。

[14] Mike Crang, Cultural Geography, Yang Shuhua and others. Nanjing: Nanjing UniversityPress, 2003. 迈克・布朗 《文化地理学》杨淑华 等译 南京: 南京大学出版 2003 年。

[15] Samuel j. Hurwitz, the history of Jamaica. Translated by Li Guobin and Feng Chengbo. Tianjin: Tianjin People'sPublishing, 1977. 塞缪尔 - J 赫维茨: 《牙买加史》黎国涁、冯承柏译 天津: 天津人民出版社 1977 年。 